Efektor, Volume 8 Issue 2,2021, Pages 154-166

Available online at:http://ojs.unpkediri.ac.id/index.php/efektor-e

DOI: https://doi.org/10.29407/e.v8i2.16234

\title{
Pengembangan Media Pembelajaran Interaktif Budaya Jawa Untuk Menstimulasi Kesantunan Bahasa Pada Anak Usia 5-6 Tahun
}

\author{
Adea Jery Nurafitri ${ }^{1}$, Epritha Kurnia Wati ${ }^{2}$, Intan Prastihastari Wijaya ${ }^{3}$ \\ adeajery22@gmail.com,epritha@unpkediri.ac.id,intanwijaya@unpkediri.ac.id \\ 1,2,3 PG-PAUD- Universitas Nusantara PGRI Kediri
}

\begin{abstract}
Today's millennial generation, politeness in language is fading, in Javanese society, it is rare for us to meet someone who uses it, so this will have an impact on early childhood language development, especially on politeness. In addition, the current generation of Java is very minimal in using the Java language correctly. Politeness in Javanese has a very useful role in a person's behavior, because language is an expression that includes traits and behavior for Javanese people. Based on the results of observations that have been carried out by researchers at the Gurah District Kindergarten Institution, it shows that language politeness in children aged 5-6 years is very low. very close there are still many children who use language that is less polite when speaking. The purpose of this research is to stimulate language politeness with interactive learning media of Javanese culture. This research technique uses the Research and Development type of research for the research model using the Lee \& Owens development model, this model was chosen because at the implementation stage it is easy and practical so it is very suitable to be used as Microsoft Office Power Point-based product development, namely interactive learning of Javanese culture. The results of this study can be seen in the evaluation results of media experts, amounting to 0.9 and 0.8 with very valid criteria or very feasible to use. While the material products 0.9 and 0.7 with very valid criteria or very feasible to use for the acquisition of a questionnaire of 0.7. At the small group of trial stage also obtained a result of 0.9 so that it can be categorized as very suitable for use.
\end{abstract}

Keywords: Interactive Learning Media, Javanese Politeness, Early Childhood.

\begin{abstract}
Abstrak
Generasi milenial saat ini, sikap kesantunan dalam berbahasa semakin memudar, di lingkungan masyarakat Jawa, bahasa yang santun semakian langka kita menjumpai seseorang yang menggunakannya, sehingga hal ini akan berdampak pada perkembangan Bahasa anak usia dini terutama pada kesantunannya. Selain itu generasi Jawa saat ini sangat minim menggunakan Bahasa Jawa dengan benar. Kesopanan dalam berbahasa Jawa memiliki peran yang sangat berguna dalam perilaku seseorang tersebut, karena bahasa merupakan suatu ekspresi yang mencakup sifat dan perilaku bagi masyarakat Jawa. Berdasarkan hasil observasi yang telah dilakukan peneliti di lembaga TK Kecamatan Gurah menunjukkan bahwa kesantunan berbahasa pada anak usia 5-6 tahun sangat rendah. Diketahui masih banyak anak yang menggunakan bahasa kurang santun ketika berbicara. Tujuan dari penelitian ini untuk menstimulasi kesantunan bahasa dengan media pembelajaran interaktif budaya Jawa. Teknik penelitian ini menggunakan jenis penelitian Research and Development untuk model penelitiannya menggunakan model pengembangan Lee \& Owens, model ini dipilih karena pada tahapan pelaksanaannya mudah dan praktis sehingga sangat sesuai untuk digunakan sebagai pengembangan produk berbasis Microsoft Office Power Point yaitu pembelajaran interaktif budaya Jawa. Hasil penelitian ini dapat diketahui pada hasil evaluasi ahli media, sebesar 0.9 dan 0.8 dengan kriteria sangat valid atau sangat layak digunakan. Sedangkan produk materi 0.9 dan 0.7 dengan kriteria sangat valid atau sangat layak digunakan dan layak digunakan untuk perolehan angket sebesar 0.7. Pada tahap uji coba kelompok kecil juga memperoleh hasil sebesar 0.9 sehingga dapat diktegorikan sangat layak digunakan.
\end{abstract}

Kata Kunci: Media Pembelajaran Interaktif, Kesantunan Bahasa Jawa, Anak Usia Dini. 


\section{PENDAHULUAN}

Anak usia dini diartikan anak yang rentan usianya mulai bayi baru lahir sampai enam tahun (Undang-undang Sisdiknas, 2003) dan pakar anak usia dini mengukakan pendapat bahwa anak usia dini juga mencakup usia mulai lahir sampai delapan tahun. Sedangkan menurut Mansur, (dalam Habibatullah dkk., 2021)anak usia dini adalah anak yang berada pada masa proses pertumbuhan dan perkembangan yang memiliki sifat unik. Siklus pertumbuhan dan perkembangan mereka berbeda-beda sesuai dengan tingkat pertumbuhan dan perkembangannya masing-masing. Pada masa ini bisa disebut dengan masa emas atau golden age, karena pada masa ini anak mengalami pertumbuhan dan perkembangan yang sangat pesat dan tidak bisa tergantikan dimasa waktu yang akan datang.Sesuai isi dari Permendikbud No 137 tahun 2014, menjelaskan bahwa Standart Tingkat Pencapaian Perkembangan Anak Usia Dini atau yang biasanya disebut STTPA merupakan sebuah kriteria mengenai aspek kemampuan anak yang akan dicapai terdiri dari enam aspek perkembangan dan pertumbuhan, terdiri dari aspek nilai agama dan moral, fisik-motorik, kognitif, bahasa, sosial-emosional dan seni.

Bahasa merupakan ucapan pikiran dan perasaan seseorang dimana digunakan untuk berkomunikasi antara satu orang dengan orang lainnya yang meliputi menyimak, berbicara, membaca dan menulis Hurlock (Anggraini dkk., 2019). Aspek perkembangan bahasa pada anak usia dinipoin utamanya yaitu memberikan tekanan untuk bisa mendengar dan bisa berbicara, bukan bisa menulis maupun bisa membaca. Hal ini disebabkan karena adanya hubungan kesiapan organ pendengaran dan berbicara yang dipengaruhi oleh kekuatan sensori motor. Kekuatan organ ini, akanbepotensi menjadi lebih unggul terkait dengan kesiapan otaknya dan mempermudah anak untuk memperoleh bahasa yang lebih utuh (Lestariningrum \& Wijaya, 2019).Karena bahasa ini hal yang sangat penting dimiliki anak untuk bersekolah maupun dalam kehidupannya. Aspek perkembangan bahasa ini harus diperoleh anak, untuk komponen pengembangan bahasa yaitu dengan membaca, menulis, menyimak dan berbicara. Aspek perkembangan Bahasa dapat dikembangkan melalui metode-metode bercerita, bermain peran, bernyanyi, bercakap-cakap, sosiodrama serta tanya jawab. Tetapi untuk aspek bahasa anak usia dini poin utamanyaditekankanpada berbicara dan mendengar, bukan menulis dan membaca. Untuk indikator yang dimiliki aspek perkembangan bahasa salah satunya yaitu Bahasa Jawa atau bahasa daerah.

Indonesia memiliki berbagai macam Bahasa Daerah, akan tetapi Bahasa Daerah yang paling banyak digunakan yaitu Bahasa Jawa. Hal tersebut biasa disebut sebagai bahasa ibu bagi masyarakat etnis Jawa, dikarenakan pada dasarnya Bahasa Jawa salah satu bagian dari media yang dipakai dalam masyarakat Jawa untuk berkomunikasi.Menurut Poedjosoedarmo, (dalam Qasanah, 2018)bahasa Jawa ini memiliki ciri khas yang beda dengan bahasa daerah lainnya. Pada bahasa Jawa ini mengandung tingkat tutur sistem kode penyampaian rasa kesantunan yang pada dasarnya terdapat kosakata, sistaksis tertentu, morfologi dan aturan fonologi. Dalam setiap ucapan tutur kata bahasa Jawa mengandung makna yang terkandung di dalamnya. Tingkatan tutur kata yang halus menandakan tingkat rasa kesopanan yang tinggi, tingkatan tutur kata menengah digunakan pada tingkat kesopanan yang sedang-sedang, sedangkan untuk tingkat tutur yang rendah digunakan sebagai cerminan kesopanan yang rendah. Dalam tata bahasa Jawa tingkat tutur kata dibedakan menjadi dua yaitu tingkat tutur kata bahasa Jawa Ngoko dan bahasa Jawa Krama.Kesopanan dalam berbahasa Jawa 
berperan sangat penting dalam perilaku seseorang tersebut, karena bahasa baggian dari suatu ekspresi yang mencakup sifat dan perilaku bagi masyarakat Jawa, menurut Sartini (dalam Budiastuti \& Khamidun, 2019). Kesantunan bahasa juga memiliki pengertian, yang mana juga termasuk indikator pada pendidikan karakter.Menurut Mustika (dalam Apriliani dkk., 2020) kesantunan berbahasa merupakan aspek yang dapat membentuk sebuah karakter bangsa yang baik bagi kalangan orang Jawa.Sedangkan menurut (Cahyadi, 2018), mengungkapkan bahwa apabila perilaku orang tersebut diekspresikan dengan dengan etika yang baik maka bisa disebut dengan kesantunan. Oleh sebab itu ketika orang Jawa tidak menerapkan kesopanan dalam berbahasa Jawa maka orang tersebut sudah dikatakan sebagai orang yang tidak memiliki karakter baik.

Berdasarkan pemerolehan hasil observasi yang telah dilakukan peneliti di lembaga TK Kecamatan Gurah menunjukkan bahwa kesantunan berbahasa pada anak usia 5-6 tahun sangat rendah. Diketahui masih banyak anak yang menggunakan bahasa kurang sopan ketika berbicara.Pada generasi milenial saat ini, sikap kesantunan dalam berbahasa semakin memudar. Di lingkungan masyarakat Jawa, bahasa yang santun semakian langka kita menjumpai seseorang yang menggunakannya, sehingga hal ini akan berdampak pada perkembangan bahasa anak usia dini terutama pada kesantunannya. Selain itu generasi Jawa saat ini ketika berbicara belum menggunakan Bahasa Jawa dengan benar dan tepat. Oleh sebab itu pendidikan anak usia dini seharusnya diterapkan pembelajaran dan pembiasaan kesantunan dalam berbahasa Jawa. Karena pada masa usia keemasan ini sangat baik untuk menstimulasi perkembangan bahasa anak. Tetapi pada kenyataanya guru hanya menggunakan LKA maupun dengan metode ceramah dalam menstimulasi kesantunan berbahasa Jawa anak, guru jarang memanfaatkan media pembelajaran interaktif sehingga anak merasa bosan dan tidak tertarik. Hal tersebut menjadikan anak tidak tertarik dalam mengikuti pembelajaran.Menurut penelitian (Apriliani dkk., 2020) menjelaskan bahwa penggunaan media pembelajaran memang cocok digunakan anak usia dini, karena karakteristik anak usia dini belum bisa mendefinisikan hal-hal yang tidak berwujud.Oleh karena itu, begitu pentingnya penggunaan media pembelajaran interaktif ketika memberikan suatu konsep yang tidak berwujud, seperti halnya kesantunan berbahasa ini.

Peneliti berupaya dalam mengatasi permasalahan tersebut dengan membuat sebuah media pembelajaran interaktif berbasis budaya Jawa. Media pembelajaran interaktif berbasis Bahasa Jawa ini, dibuat dengan memanfaatkan aplikasi Microsoft office power point yang mana pada aplikasi tersebut bisa digunakan untuk membuat sebuah video interaktif. Microsoft powerpoint ini merupakan salah satu bagian dari program yang berbasis multimedia. Aplikasi software ini, terdapat fasilitas berupa slide-slide yang digunakan untuk membantu membuat sebuah presentasi yang professional, efektif dan juga mudah. Sehingga dalam penggunaannya untuk proses pembelajaran dirasa sangat bermanfaat, Azhar (dalam Hikmah \& Maskar, 2020). Fitur-fitur yang terdapat pada powerpoint juga banyak dan menarik seperti pengolahan teks, bisa untuk menyisip kan gambar, terdapat audio, animasi dan efek yang bisa digunakan sesuai keinginan, sehingga tayangan-tayangannya akan membuat daya tarik terhadap peserta didik (Misbahudin dkk, 2018). Media tersebut pada nantinya akan berisi materi mengenai tingkatan berbahasa Jawa, budaya-budaya yang ada disekitar dan lagu daerah.Materi tersebut oleh peneliti akan dikembangkan menjadi materi yang menarik dan menyenangkan melalui video interaktif, sehingga anak juga bisa terlibat untuk memainkan media tersebut. Dari tayangan media ini, anak akan mengetahui Bahasa Jawa dengan ciri-ciri khasnya, bahasa yang sopan ketika berbicara dan anggun. Media juga bisa digunakan oleh pendidik sebagai alat untuk menarik minat peserta didik selama proses 
pembelajaran, Mansur (dalam Safrina \& Munzir, 2020). Media pembelajaran interaktif Bahasa Jawa ini bertujuan untuk menstimulasi kesantunan berbahasa pada anak usia 5-6 tahun serta menambah wawasan kecintaan pada budaya-budaya yang dimiliki oleh masyarakat Jawa sebagai pembentukan karakter yang kuat bangsa Indonesia.

Melalui perantara media, pesan atau informasi yang akan disampaikan oleh pengirim dapat diterima penerima dengan mudah dan baik. Menurut Kurniawati (2018), bahwa media merupakan bentuk sarana yang digunakan untuk menyampaikan informasi atau pesan.Selain itu media disebut sebagai faktor yang sangat penting demi mendukung keberhasilan dalam belajar dan mengajar yang dilakukan guru dan siswa sehingga melalui media penyampaian informasi dapat berjalan dengan baik. Menurut (Wahyudi dkk., 2019)media interaktif merupakan media alternatif yang berperan sebagai alat penyampaian informasi. Pada media interaktif ini terdapat berbagai macam teks, kombinasi grafik, suara, video, dan animasi. Penggabungan tersebut merupakan satu kesatuan dari sebuah media yang digunakan dengan tujuan untuk menyajikan informasi, pesan atau isi pelajaran secara menarik, menyenangkan, mudah dimengerti, dan jelas. Sedangkan arti media Interaktif menurut (Faris \& Lestari, 2016) merupakan suatu sistem media yang penyampaiannya melalui sebuah tayangan video dengan menggunakan alat bantu Komputer kepada pengguna yang tidak hanya mendengar ataupun melihat saja, tetapi juga memberikan sebuah respon terhadap apa yang ada pada tayangan video tersebut. Sejalan dengan pendapat (Zaini \& Saputri, 2017) bahwa media interaktif adalah sebuah alat untuk menyampaikan informasi yang harus melibatkan pengguna dengan media, dengan begitu akan memungkinkan bahwa setiap orang yang berbeda untuk mengalami alur yang berbeda pada pengguna media.

Penggunaan media pembelajaran merupakan hal yang sangat berguna agar menambah daya tarik dan minat anak, karena dengan media bisa memberikan sebuah solusi dari keterbatasan daya indera, ruang dan waktu, Dadan Djuanda (dalam Kurniawati, 2018). Karena media membawa pengaruh yang besar dalam proses pembelajaran. Sesuai dengan pendapat (Erfan \& Turrahmi, 2018)mengatakan bahwa ketika menggunakan media maka proses belajar mengajar akan merubah cara pandang bahasa, yang dulu biasa disebut mengajar, maka saat ini media berubah menjadi sebuah bahasa media yang mampu membawa peserta didik yang bisa membujuk, membahagiakan hati, penuh dengan getaran, irama, cerita dan gambar-gambar secara visualisasi. Sehingga peserta didik akan merasa tertarik untuk memperhatikan selama proses pembelajaran yang bersifat auditif dan visualitatif.

\section{METODE PENELITIAN}

Penelitian dan pengembangan pembelajaran interaktif ini ditujukan pada pembelajaran anak kelompok B, peneliti memilih menggunakan model pengembangan (Lee \& Owens, 2004). Model ini dipilih karena terdapat tahap-tahap pelaksanaan yang mudah dan praktis sangat sesuai untuk digunakan sebagai pengembangan produk berbasis Microsoft office power point yaitu pembelajaran interaktif budaya Jawa. Model pengembangan Lee \& Owens ini memiliki prosedur penelitian pengembangan yang terdiri dari, analisis, desain, pengembangan, implementasi dan evaluasi.Adapun gambaran langkah-langkah pembuatan media pengembangan sebagai berikut. 
Efektor, Volume 8 Issue 2,2021, Pages 154-166

Adea Jery Nurafitri1, Epritha Kurnia Wati2, Intan Prastihastari Wijaya ${ }^{3}$



Gambar 1 Langkah-langkah Pembuatan Media Pengembangan

Pada analisi kebutuhan peneliti akan melakukan sebuah penelitian dan pegumpulan data informasi melalui pengamatan kelas pada kelompok B. Dilanjutkan dengan penyusunan berupa desain pengembangan yang akan dibuat untuk media pembelajaran interaktif, meliputi struktur isi, yang merupakan materi nantinya akan menjadi isi dari produk sesuai dengan metode yang telah ditentukan.Pada tahap pengembangan produk berupa media pembelajaran interaktif budaya Jawa berisikan materi mengenai kesantunan dalam berbahasa Jawa yang terdiri dari penggunaan kosa-kata yang baik dan benar, tingkah laku keseharian yang santun, lagu-lagu daerah sebagai bentuk pengenalan budaya pada anak usia dini dan terdapat rekaman suara yang berisikan pengucapan sesuai dengan apa yang ditampilkan pada tayangan tersebut. Selain itu juga terdapat game sebagai bentuk untuk mengukur tingkat capaian anak terhadap materi yang telah didapatkannya dengan menggunakan media pembelajaran interaktif budaya Jawa. Selanjutnya tahap Implementasi produk ini yang sudah selesai dikembangkan akan di uji cobakan. Uji coba dilakukan dengan menggunakan uji coba kelompok kecil yang terdiri dari 5 anak kelompok B usia 5-6 tahun uji coba ini hanya dilakukan hanya sampai tahap uji coba kelompok kecil. Untuk yang terakhir terdapat evaluasi, yang dilakukan peneliti adalah validasi produk oleh ahli media dan ahli materi pembelajaran anak usia dini pada bidang bahasa. Validasi ahli dilakukan dengan tujuan agar mendapatkan saran dari para ahli dengan maksud untuk menyempurnakan menjadi produk akhir yang bagus.

Lokasi dan subyek penelitian ini dilakukan di Kecamatan Gurah pada TK Dharma Wanita Kranggan yang meliputi anak usia 5-6 tahun. Validasi produk dilakukan dengan meminta bantuan kepada dua ahli materi dan dua ahli media sebagai langkah untuk proses. Instrument yang dilakukan pada penelitian ini terdiri dari kemudahan, kemenarikan, kesesuaian, ketepatan, keefektifan, Berikut ini Tabel skala untuk menilai angket ahli media dan ahli materi:

Untuk memberi skor pada angket ahli media dan ahli materi sebagai pedoman penyekoran berupa skala likert dengan skala 1-5

Tabel 1. Skala Penilaian Angket (Sudijono, 2001)

\begin{tabular}{|c|c|c|c|c|}
\hline \multicolumn{5}{|c|}{ SKALA PENILAIAN TANGGAPAN } \\
\hline 5 & 4 & 3 & 2 & 1 \\
\hline Sangat Sesuai & Sesuai & Cukup Sesuai & Kurang Sesuai & $\begin{array}{ll}\text { Sangat Kurang } \\
\text { Sesuai }\end{array}$ \\
\hline Sangat Jelas & Jelas & Cukup Jelas & Kurang Jelas & $\begin{array}{l}\text { Sangat Kurang } \\
\text { Jelas }\end{array}$ \\
\hline Sangat Menarik & Menarik & Cukup Menarik & Kurang Menarik & $\begin{array}{l}\text { Sangat Kurang } \\
\text { Menarik }\end{array}$ \\
\hline Sangat Mudah & Mudah & Cukup Mudah & Kurang Mudah & $\begin{array}{l}\text { Sangat Kurang } \\
\text { Mudah }\end{array}$ \\
\hline Sangat Tepat & Tepat & Cukup Tepat & Kurang Tepat & $\begin{array}{l}\text { Sangat Kurang } \\
\text { Tepat }\end{array}$ \\
\hline
\end{tabular}


Efektor, Volume 8 Issue 2,2021, Pages 154-166

Adea Jery Nurafitri1, Epritha Kurnia Wati2, Intan Prastihastari Wijaya ${ }^{3}$ dua yaitu:

Rumus yang digunakan untuk menolah data angket menurut Sugioyo (2011) terbagi menjadi

Rumus untuk mengolah data secara keseluruhan item adalah:

Keterangan :

$$
V m=\frac{\epsilon x}{\in x i} \times 100 \%
$$

$\mathrm{Vm}$ : Persentase kevalidan

$\sum X$ : Jawaban responden dalam satu item

$\sum X i$ Jawaban nilai ideal

Tabel 2. Kriteria tingkat Keberhasilan (Sudijono, 2001)

\begin{tabular}{cccc}
\hline Kategori & Koefisian Korelasi & Kualifikasi & Ekuivalen \\
\hline A & $0.800-1.00$ & Sangat Valid & Sangat Layak \\
\hline B & $0.600-0.800$ & Valid & Layak \\
\hline C & $0.400-0.600$ & Cukup Valid & Cukup Layak \\
\hline D & $0.200-0.400$ & Kurang Valid & Kurang Layak \\
\hline E & $0.00-0.200$ & Sangat Tidak Valid & Sangat Tidak Layak \\
\hline
\end{tabular}

\section{HASIL DAN PEMBAHASAN}

Hasil dari yang telah dilakukan oleh peneliti yaitu berupa produk media pembelajaran interaktif berbasis budaya Jawa. Produk media pembelajaran interaktif berbasis budaya Jawa ini dibuat dalam bentuk Microsoft Office power point yang berisikan materi mengenai kesantunan berbahasa Jawa dan pengenalan budaya Jawa yang santun, terdapat juga petunjuk penggunaan pada media untuk memudahkan dalam penggunaan media, dilengkapi juga dengan gamesebagai bentuk analisis seberapa jauh hasil dari pemahaman materi yang telah diberikan melalui media interaktif. Berikut hasil dari produk pengembangan media pembelajaran interaktif berbasis budaya Jawa, antara lain.

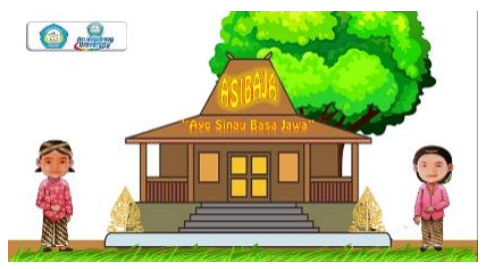

Gambar 1. Tampilan menu pembuka

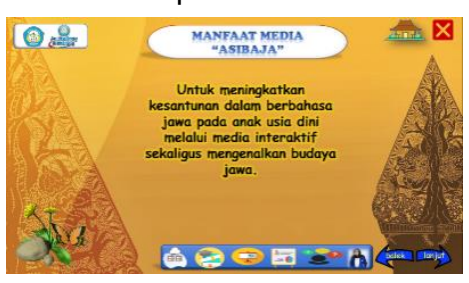

Gambar 4. Tampilan menu manfaat

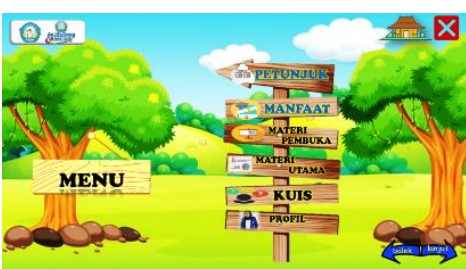

Gambar 2. Tampilan menu awal



Gambar 5. Tampilan materi pembuka

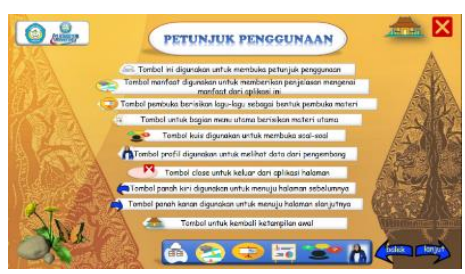

Gambar 3. Tampilan petunjuk penggunaan

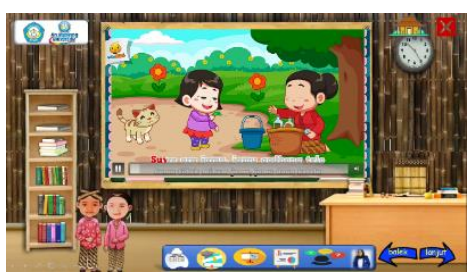

Gambar 6. Tampilan lagu daerah Jawa 


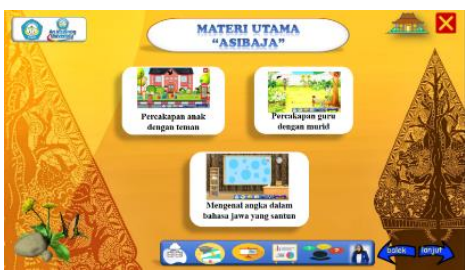

Gambar 7. Tampilan menu materi utama

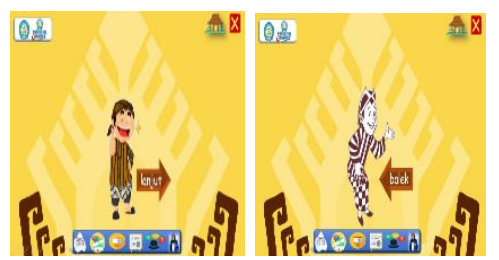

Gambar 10. Tampilan menu benar \& salah

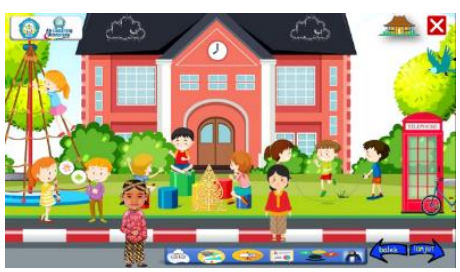

Gambar 8. Tampilan materi

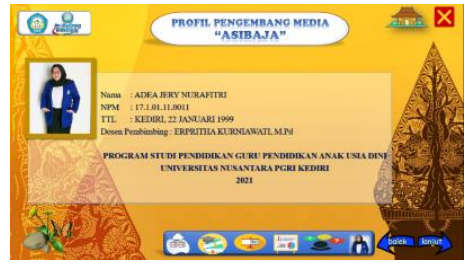

Gambar 11. Tampilan profil pengembang

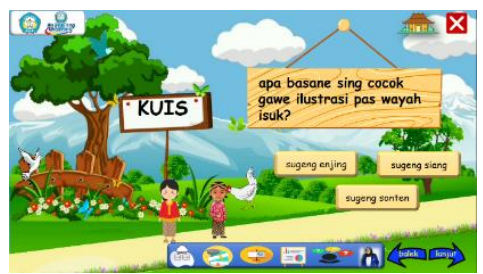

Gambar 9. Tampilan salah satu kuis

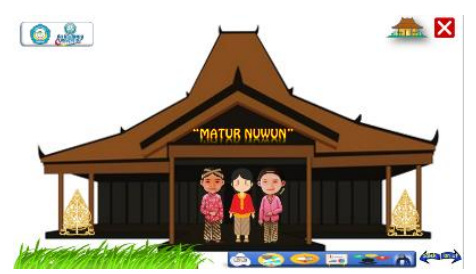

Gambar 12. Tampilan menu penutup

Analisis Data Hasil Penelitian

a) Validitas konstruk

Berdasarkan data hasil validasi kepada dua ahli media diperoleh hasil perhitungan per aspek sebagai berikut.

1) Berdasarkan kriteria kelayakan, aspek yang dapat dikategorikan dalam kualifikasi sangat valid atau sangat layak dari hasil ahli media Ibu Widi Wulansari dengan nilai $0.800-1.00$ meliputi, tingkat kemudahan penggunaan bahasa, materi, cerita, daya tarik opening, kejelasan dan kemenarikan gambar serta backsound musik, kemenarikan animasi dan desain warna, keefektifan media pembelajaran interaktif dengan media lainnya, keefektifan digunakan sebagai aat ukur peserta didik, ketepatan pemilihan (jenis huruf, warna pemilihan tombol, tokoh animasi dengan suara, pemilihan suara dan daya dukung musik, penyusunan media) kesesuaian gambar dengan materi, kesesuaian warna background dengan teks. Untuk hasil yang kualifikasinya valid atau layak yaitu dengan nilai 0.600-0.800 antara lain,tingkat kemudahan menggunakan media pembelajaran, kemudahan dalam pengoperasian media pembelajaran, kejelasan petunjuk penggunaan sumber belajar, keefektifan dengan menggunakan media lainnya dan digunakan sebagai alat ukur keberhasilan peserta didik, kelengkapan media dan gambar sesuai dengan materi.

2) Berdasarkan kriteria kelayakan, aspek yang dapat dikategorikan dalam kualifikasi valid atau layak dari hasil ahli media Ibu Linda Dwiyanti dengan nilai $0.600-0.800$ yaitu tingkat kemudahan dalan meggunakan media pembelajaran, kemudahan dalam memahami cerita dan pengoperasian media pembelajaran, daya tarik opening, kejelasan petunjuk penggunaan sumber belajar, gambar terlihat jelas dan menarik, kemenarikan backsound musik, animasi gambar dan juga kemenarikan desain warna dan background, keefektifan media untuk digunakan sebagai alat ukur keberhasilan peserta didik, ketepatan pemilihan jenis huruf, warna, pemilihan tombol, gerakan tokoh animasi dengan suara, ketepatan pemilihan suara dan daya dukung musik, ketepatan penyusunan media, kesesuaian gambar dengan materi, kesesuaian dala pemilihan warna, gambar, gambar dengan materi, background dengan teks, kelengkapan media sesuai dengan materi dan kelengkapan gambar dengan materi. Untuk hasil yang kualifikasinya cukup valid atau cukup layak yaitu 
dengan nilai $0.400-0.600$ yang meliputi tingkat kemudahan dalam penggunaan bahasa dan materi.

Berdasarkan pengolahan dari data dua ahli media tersebut, maka dapat diperoeh 0.9 untuk hasil yang didapatkan dari lbu Widi Wulandari dan 0.8 untuk hasil yang didapatkan dari ibu Linda Dwiyanti. Sehinggaproduk media pembelajaran interaktif berbasis budaya Jawa bisa diterapkan dalammenstimulai kesantunan Bahasa Jawa pada anak usia dini dengan kriteria sangat valid atau sangat layak dan sudah dapat untuk digunakan dalam kegiatan pembelajaran anak TK Kelompok B pada usia 5-6 tahun.

Produk ini bisa dikatakan layak karena pada nilai aspek (1) kemudahan dalam memahami cerita, materi, dan pengoperasian media pembelajaran, (2) daya tarik opening, kemenarikan gambar dan kejelasan, kemenarikan backsound musik dengan materi pembelajaran, keterbacaan teks, kemenarikan animasi gambar, kemenarikan desain warna dan background, (3) keefektifan media pembelajaran untuk dijadikan tolak ukur keberhasilan peserta didik, (4) ketepatan pemilihan jenis huruf, warna, pemilihan tombol, gerakan tokoh animasi dengan suara, pemilihan suara dengan daya dukung musik, penyusunan media, (5) kesesuaian gambar dengan materi, pemilihan warna dan gambar, gammbar dengan materi, warna background dengan teks, (6) kelengkapan media sesuai dengan materi dan gambar dengan materi. Memperoleh nilai tertinggi dan bisa dikategorikan sangat layak.

b) Validasi Isi

Berdasarkan data hasil validasi kepada dua ahli materi didapatkan hasil perhitungan per aspek sebagai berikut.

1) Berdasarkan kriteria kelayakan, aspek yang dapat dikategorikan dalam kualifikasi sangat valid atau sangat layak dari hasil ahli materi Bapak Dr. Dema Yulianto, M.Psi dengan nilai 0.800 - 1.00yang meliputi daya tarik opening, kemenarikan materi dalam meningkatkan rasa cinta anak terhadap Budaya Jawa, kesesuaiandalam pemilihan warna dan gambar. Untuk hasil yang kualifikasinya valid atau layak yaitu dengan nilai $0.600-0.800$ meliputi tingkat kemudahan dalam penggunaan bahasa, kemudahan memahami materi dan cerita, kemudahan pengoperasian media pembelajaran, kejelasan petunjuk penggunaan sumber belajar, gambar terlihat jelas menarik, kemenarikan backsound musik dengan materi, keterbacaan teks, kemenarikan animasi gambar, keefektifan materi untuk digunakan sebagai alat ukur keberhasilan, keteapatan materi untuk menstimulasi kesantunan bahasa, ketepatan dalam pemilihan materi berupa tayangan lagu, ketepatan gerakan tokoh animasi dengan suara, ketepatan dalam pemilihan suara dan daya dukung musik, ketepatan penyusunan media, kesesuaian gambar dengan karakteristik sasaran, kesesuaian gambar dengan materi, kesesuaian warna background dengan teks, kelengkapan media sesuai dengan materi dan kelengkapan gambar dengan materi.

2) Berdasarkan kriteria kelayakan, aspek yang dapat dikategorikan dalam kualifikasi valid atau layak dari hasil ahli materi lbu Dr. Anik Lestariningrum, M.Pd dengan nilai 0.6000.800 yang meliputi tingkat kemudahan dalam penggunaan bahasa, kemudahan dalam memahami cerita, daya tarik opening, kejelasan petunjuk penggunaan sumber belajar, keterbacaan teks, kemenarikan animasi gambar, kemenarikan materi dalam meningkatkan rasa cinta anak terhadap Budaya Jawa, keefektifan materi untuk anak usia 5-6 tahun, keefektifan untuk digunakan sebagai alat ukur keberhasilan peserta didik, ketepatan dalam pemilihan materi berupa tayangan lagu, ketepatan penyusunan media, kesesuaian gambar dengan karakteristik sasaran,kesesuaian dalam pemilihan warna dan gambar.Untuk hasil yang kualifikasinya cukup valid atau cukup layak yaitu dengan nilai 0.400-0.600meliputi kemudahan dalam memahami materi, kemudahan pengoperasian media pembelajaran, 
gambar terlihat jelas dan menarik, kemenarikan backsound musik dengan materi pembelajaran, ketepatan materi untuk menstimulasi kesantunan bahasa, ketepatan gerakan tokoh animasi dengan suara, ketepatan pemilihan suara dan daya dukung musik, kesesuaian gambar dengan materi, kesesuaian gambar background dengan teks, kelengkapan media sesuai dengan materi, kelengkapan gambar dengan materi.

Berdasarkan pengolahan dari data dua ahli materi tersebut, maka dapat diperoeh 0.9 untuk hasil dari bapak Dema Yulianto dan 0.7 untuk hasil dari ibu Anik Lestariningrum. Sehingga produk media pembelajaran interaktif berbasis budaya Jawa bisa diterapkan dalam menstimulai kesantunan Bahasa Jawa pada anak usia dini dengan kriteria sangat valid atau sangat layak dan sudah dapat untuk digunakan dalam kegiatan pembelajaran anak TK Kelompok B pada usia 5-6 tahun.

Produk ini bisa dikatakan sangat layak karena pada nilai aspek (1) Tingkat kemudahan penggunaan bahasa, memahami cerita dan materi, pengoperasian media pembelajaran. (2) daya Tarik opening, petunjuk penggunaan sumber belajar, gambar terlihat jelas dan menarik, kemenarikan backsound musik dengan materi pembelajaran, kemenarikan animasi gambar, kemenarikan materi dalam meningkatkan rasa cinta anak terhadap budaya jawa, (3) keefektifan materi untuk anak usia 5-6 tahun, keefektifan untuk digunakan sebagai alat ukur keberhasilan peserta didik, (4) ketepatan materi untuk menstimulasi kesantunan bahasa, ketepatan dalam pemilihan materi berupa tayanga lagu, ketepatan gerakan tokoh animasi dengan suara, ketepatan dalam pemilihan suara dan daya dukung musik, ketepatan penyusunan media, (5) kesesuaian gambar dengan karakteristik sasaran, kesesuaian dalam pemilihan warna dan gambar, kesesuaian warna background dengan teks, (6) kelengkapan media sesuai dengan materi, kelengkapan gambar dengan materi. Sehingga memperoleh nilai tertinggi dan bisa dikategorikan sangat layak.

c) Validasi Kemudahan dan Kemenarikan

Berdasarkan data hasil validasi kepada Guru Kelas tentang kemudahan dan kemenarikan didapatkan hasil perhitungan per aspek sebagai berikut. Kriteria kelayakan, aspek yang dapat dikategorikan dalam kualifikasi sangat valid atau sangat layak dari hasil Guru Kelas Ibu Dheni Tri Andayani dengan nilai 0.800 - 1.00yang meliputi kemudahan dalam memahami materi dan cerita, kemudahan pengoperasian media pembelajaran, daya tarik opening, kejelasan petunjuk penggunaan sumber belajar, gambar terlihat jeas dan menarik, keterbacaan teks, kemenarikan animasi gambar, kemenarikan desain warna dan background, kemenarikan materi dalam meningkatkan rasa cinta anak terhadap budaya jawa. Untuk hasil yang kualifikasinya valid atau layak yaitu dengan nilai $0.600-0.800$ meliputi tingkat kemudahan dalam menggunakan media pembelajaran, tingkat kemudahan dalam penggunaan bahasa dan kemenarikan backsound musik dengan materi.

Berdasarkan pengolahan dari data Uji Coba kelompok kecil oleh Guru Kelas tersebut, maka dapat diperoleh 0.9. Dimana hasil tersebut bisa diterapkan dalam menstimulai kesantunan Bahasa Jawa pada anak usia dini dengan kriteria dini sangat valid atau sangat layak dan sudah dapat untuk digunakan dalam kegiatan pembelajaran anak TK usia 5-6 tahun.

Produk ini bisa dikatakan sangat layak karena pada nilai aspek (1) kemudahan dalam menggunakan media, memahami materi, ceruta dan pengoperasian media pembelajaran, (3) Kemanarikan daya tarik opening, kejelasan petunjuk penggunaan sumber belajar, gambar terlihat jelas dan menarik, keterbacaan teks, kemenarikan animasi gambar, kemenarikan desain warna dan background, kemenarikan materi dalam meningkatkan rasa cinta anak terhadap budaya Jawa. Sehingga memperoleh nilai tertinggi dan bisa dikategorikan sangat layak. 
Efektor, Volume 8 Issue 2,2021, Pages 154-166

Adea Jery Nurafitri1, Epritha Kurnia Wati2, Intan Prastihastari Wijaya ${ }^{3}$

Setelah melakukan beberapa tahapan validasi media dan validasi materi, maka dapat diperoleh hasil data kuantitatif secara lengkap yang terdapat pada tabel berikut ini.

Tabel 4. Hasil Data

\begin{tabular}{|c|c|c|c|}
\hline No & Responden & Rata-rata & Kriteria \\
\hline \multirow[t]{3}{*}{1.} & Ahli Media: & & \\
\hline & Satu & 0.9 & Sangat Valid/Sangat Layak \\
\hline & Dua & 0.8 & Sangat Valid/Sangat Layak \\
\hline \multirow[t]{3}{*}{2.} & Ahli Materi: & & \\
\hline & Satu & 0.9 & Sangat Valid/Sangat Layak \\
\hline & Dua & 0.7 & Valid/Layak \\
\hline \multirow[t]{2}{*}{3.} & $\begin{array}{l}\text { Uji Coba Kelompok Kecil } \\
\text { Kemudahan dan Kemenarikan }\end{array}$ & & \\
\hline & Guru Kelas & 0.9 & Sangat Valid/Sangat Layak \\
\hline
\end{tabular}

Penggunaan media pembelajaran interkatif berbasis budaya ini sangat bagus diterapkan untuk pembelajaran anak usia dini, karena anak akan mengenal budaya daerahnya sendiri yaitu budaya Jawa. Selain itu tidak kalah pentingnya pada aspek bahasa anak yaitu mengenai kesantunan bahasanya akan terstimulasi dengan adanya media ini. Dalam media tersebut terdapat tayangantayangan mengenai kehidupan keseharian yang sering kita lakukan yang mengajarkan kesantunan dlam berbicara pada lawan bicaranya baik dengan sesamea teman ataupun dengan yang lebih tua. Hal ini bisa diketahui bahwa selama melakukan tahap uji coba kelompok kecil sebanyak 5 orang anak yang berusia 5-6 tahum, anak merasa senang dan tertarik pada media pembelajaran interaktif berbasis budaya Jawa ini. Karena pada animasi-animasinya sangat menarik selain itu juga didukung dengan backsound yang mampu membawa suasana lebih menyenangkan untuk belajar. Stimulasi menggunakan lagu-lagu daerah yang menggunakan Bahasa Jawa ternyata juga sesuai pada karakteristik anak usia dini, lagu tersebut bisa menambah nilai positif untuk anak karena anak akan lebih mencintai budayanya sendiri sejak usia dini dari pada menyukai budaya luar yang saat ini banyak budaya luar berada disekitar ruang lingkup anak. Anak-anak ketika mengerjakan kuis yang berada pada media tersebut juga sangat antusias dan tidak merasa bosan, dan tujuan yang akan dicapai bisa tersampaikan dengan baik pada anak-anak.Akan tetapi dalam penggunaan media tersebut masih terdapat kendala-kendala yang harus dibenahi yaitugame dalam media terlalu berat sehingga terkadang error, selain itu pertanyaan dan jawaban (percakapan ibu dan anak) sebaiknya dibuat lebih singkat dan sederhana untuk anak usia dini, dan yang dekat dengan kehidupan sehari- hari anak.

Berikut ini tabel foto-foto hasil dari uji coba kelompok kecil yang dilakukan sebanyak 5 anak pada usia 5-6 tahun.

Tabel 5: Dokumentasi Pelaksanaan Penelitian

\begin{tabular}{|c|c|l|}
\hline No & Hasil Foto & \multicolumn{1}{c|}{ Keterangan } \\
\hline 1. & $\begin{array}{l}\text { Kegiatan pengenalan cara penggunaan } \\
\text { media pembelajaran interaktif pada anak } \\
\text { sejumlah 5 anak. Kegiatan ini dilakukan } \\
\text { dirumah salah satu anak karena pada saat } \\
\text { ini sistem pembelajaran tidak dilakukan di } \\
\text { lingkungan sekolah karena adanya } \\
\text { Pandemi. }\end{array}$ \\
\hline
\end{tabular}


Efektor, Volume 8 Issue 2,2021, Pages 154-166

Adea Jery Nurafitri1, Epritha Kurnia Wati2, Intan Prastihastari Wijaya ${ }^{3}$

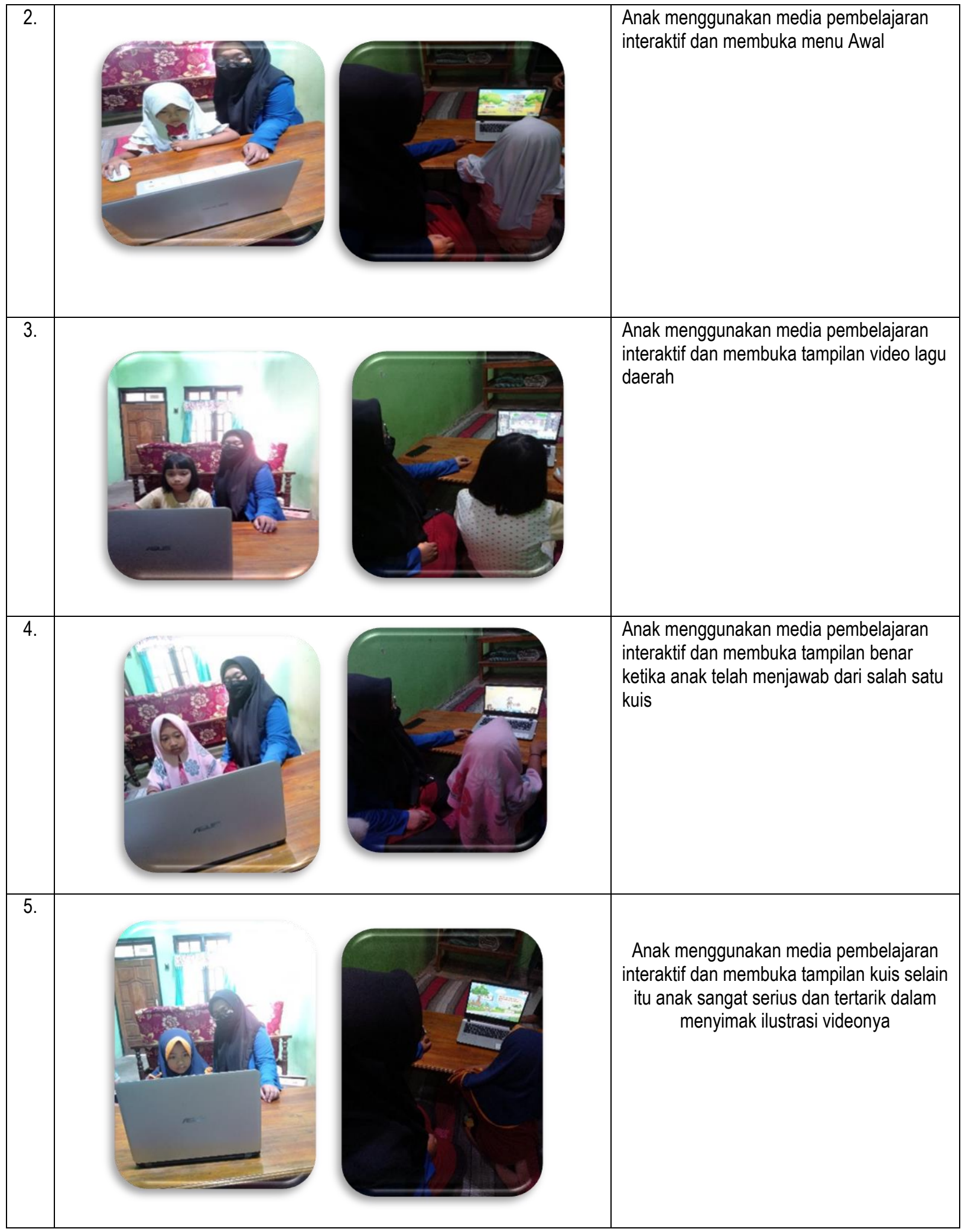


Efektor, Volume 8 Issue 2,2021, Pages 154-166

Adea Jery Nurafitri1, Epritha Kurnia Wati2, Intan Prastihastari Wijaya ${ }^{3}$

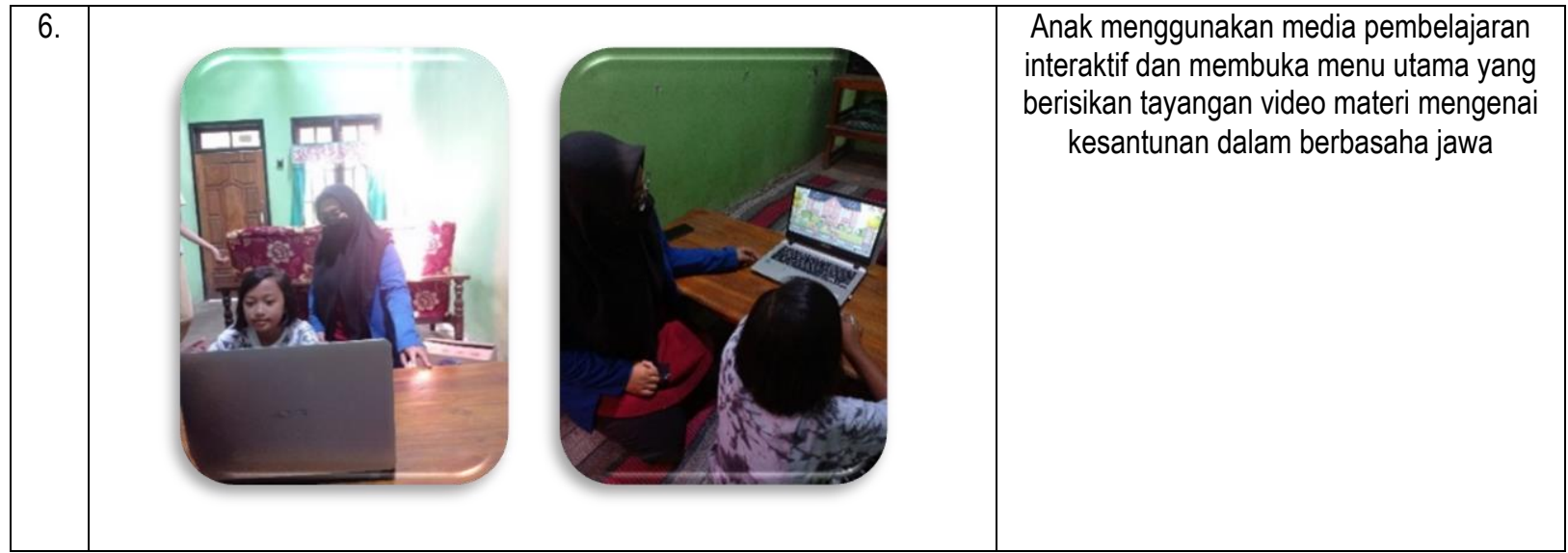

Tabel 5. Hasil Kegiatan Uji Coba Kelompok Kecil

\section{SIMPULAN}

Berdasarkan hasil penelitian yang dilaksanakan, diketahui hasil pada evaluasi dua ahli media, produk media pembelajaran interaktif berbasis budaya Jawa ini dapat digunakan dengan pemerolehan hasil persentasi dari angket sebesar 0.9 dan 0.8 dengan kriteria sangat valid atau sangat layak digunakan. Sedangkan pada produk materi pembelajaran interaktif ini dapat digunakan dengan hasil persentasi dari angket sebesar 0.9 dan 0.7 dengan kriteria sangat valid atau sangat layak digunakan dan layak digunakan pada perolehan angket sebesar 0.7. Pada tahap uji coba kelompok kecil juga memperoleh hasil sebesar 0.9 sehingga dapat diktegorikan sangat layak digunakan. Sehingga dapat diambil kesimpulandengan adanyapenerapan media pembelajaran interaktif berbasis budaya Jawa dapat dipakaisebagai alat menstimulasi kesantunan Bahasa pada anak usia 5-6 tahun.

\section{DAFTAR RUJUKAN}

Anggraini, V., Yulsyofriend, Y., \& Yeni, I. (2019). Stimulasi Perkembangan Bahasa Anak Usia Dini Melalui Lagu Kreasi Minangkabau Pada Anak Usia Dini. Pedagogi : Jurnal Anak Usia Dini Dan Pendidikan Anak Usia Dini, 5(2), 73. https://doi.org/10.30651/pedagogi.v5i2.3377

Budiastuti, A., \& Khamidun. (2019). Meningkatkan Kesopanan Anak Usia Dini dengan Bahasa JawaMedia Buku Cerita Bergambar. Makalah Pendidikan Anak Usia Dini, 8(1), 35-42.

Cahyadi, R. (2018). Pembelajaran Bahasa Jawa dalam Membentuk Kesantunan Berbahasa di MI Muhammadiyah Arenan Kecamatan Kaligondang Kabupaten Purbalingga. In Thesis. http://repository.iainpurwokerto.ac.id/id/eprint/4277

Erfan, M., \& Turrahmi, N. (2018). Pengembangan Media Pembelajaran Video Berbasis Microsoft Office Power Point Pada Materi Objek IPA dan Pengamatannya. February. https://doi.org/10.31227/osf.io/t6ky9

Faris, A., \& Lestari, A. F. (2016). Anak Usia Dini. Teknik Komputer, 2(1), 59-67.

Habibatullah, S., Darmiyanti, A., \& Aisyah, D. S. (2021). Potensi Bahasa Anak Usia Dini 5-6 Tahun Melalui Metode Bercerita. PAUD Lectura: Jurnal Pendidikan Anak Usia Dini, 4(02), 1-7. https://doi.org/10.31849/paud-lectura.v4i02.5315

Hikmah, S. N., \& Maskar, S. (2020). Pemanfaatan Aplikasi Microsoft Powerpoint Pada Siswa Smp Kelas Viii Dalam Pembelajaran Koordinat Kartesius. Jurnal IImiah Matematika Realistik, 1(1), 1519. https://doi.org/10.33365/ji-mr.v1i1.215 
Lestariningrum, A., \& Wijaya, I. P. (2019). Pengembangan Model Pembelajaran Berbasis Budaya Lokal di TK Negeri Pembina Kota Kediri. Jurnal PAUDIA, 8, 66-73.

Misbahudin, D., Rochman, C., Nasrudin, D., \& Solihati, I. (2018). Penggunaan Power Point Sebagai Media Pembelajaran: Efektifkah? WaPFi (Wahana Pendidikan Fisika), 3(1), 43. https://doi.org/10.17509/wapfi.v3i1.10939

Qasanah, U. (2018). Pengembangan Penguasaan Kosakata Bahasa Jawa Melalui Melalui Cerita Bergambar Pada Anak Kelompok A Di Tarbiyatul Atfal Muslimat NU II, Dawung, Pulisen, Boyolali Tahun Pelajaran 2017/2018 (Issue 21).

Safrina, J., \& Munzir, M. (2020). Penerapan Media Pop-Up Book Untuk Pemahaman Sub Tema Ketampakan Rupa Bumi Di Sekolah Dasar.Jurnal Tunas Bangsa, 7(1), 127-132.

Wahyudi, I., Bahri, S., \& Handayani, P. (2019). Aplikasi Pembelajaran Pengenalan Budaya Indonesia. Jurnal Teknik Komputer, V(1), 135-138. https://doi.org/10.31294/jtk.v4i2

Zaini, B., \& Saputri, M. P. (2017). Pengembangan Media Pembelajaran Interaktif Contextual Teaching and Learning (CTL) Untuk Siswa Pendidikan Anak Usia Dini (PAUD) di PAUD SAHABAT. Jurnal PINTER, 1(2), 90-100. 